This article was downloaded by: [New York University] On: 19 October 2014, At: 12:49

Publisher: Routledge

Informa Ltd Registered in England and Wales Registered Number: 1072954 Registered office: Mortimer House, 37-41 Mortimer Street, London W1T 3J H, UK

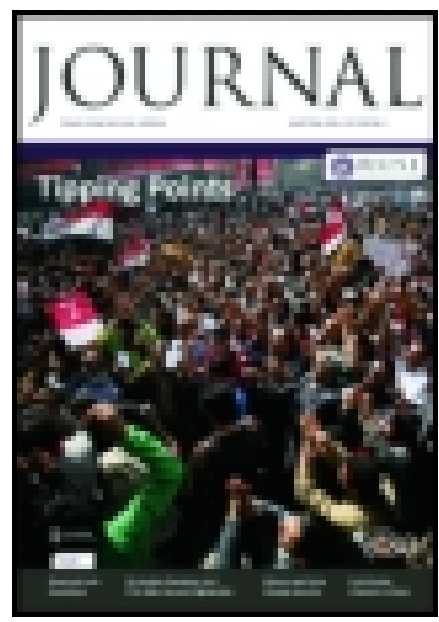

Royal United Services Institution. J ournal

Publication details, including instructions for authors and subscription information: http:// www. tandfonline.com/loi/ rusi 19

\title{
Occasional Papers and Notices of Books
}

Colonel Sir Lumley Graham Bart. ${ }^{a}$

${ }^{a}$ Royal United Service

Institution, Whitehall Yard, London, S.W.

Published online: 11 Sep 2009.

To cite this article: Colonel Sir Lumley Graham Bart. (1879) Occasional Papers and Notices of Books, Royal United Services Institution. J ournal, 23:101, 675-676, DOI: $10.1080 / 03071847909417118$

To link to this article: http://

dx. doi.org/ 10.1080/03071847909417118

\section{PLEASE SCROLL DOWN FOR ARTICLE}

Taylor \& Francis makes every effort to ensure the accuracy of all the information (the "Content") contained in the publications on our platform. However, Taylor \& Francis, 
our agents, and our licensors make no representations or warranties whatsoever as to the accuracy, completeness, or suitability for any purpose of the Content. Any opinions and views expressed in this publication are the opinions and views of the authors, and are not the views of or endorsed by Taylor \& Francis. The accuracy of the Content should not be relied upon and should be independently verified with primary sources of information. Taylor and Francis shall not be liable for any losses, actions, claims, proceedings, demands, costs, expenses, damages, and other liabilities whatsoever or howsoever caused arising directly or indirectly in connection with, in relation to or arising out of the use of the Content.

This article may be used for research, teaching, and private study purposes. Any substantial or systematic reproduction, redistribution, reselling, loan, sub-licensing, systematic supply, or distribution in any form to anyone is expressly forbidden. Terms \& Conditions of access and use can be found at http://www.tandfonline.com/page/terms-andconditions 


\section{OCCASIONAL PAPERS AND NOTICES OF BOOKS.}

This portion of the Number is reserved for Articles, either Original or Compiled, on Professional Subjects connected with Foreign Naval and Military matters; also for Notices of Professional Books, either Foreign or English.

It is requested that communications or books for review may be nddressed, during the temporary absence of Lieut.-Colonel Lonsdale Hale, to

Coloxel Sir lUMLEY GRAHAMI, Bart.,

Rojal United Service Institution,

Whitehall Yard, London, S.W.

\section{"REVUE MILTTAIRE DE L'ETRANGER."}

THe knowledge of the existence of this publication is confined to so few Officers in the English Service, that it is desirable to give to a notice of it the most prominent position in this portion of the Journal.

The Revue is a Government weekly military newspaper, edited in one of the bureaux of the French War Ministry, and ejrculated by the Government gratuitously, largely throughout the Army. The parpose of the Revue is to kcep France posted in the latest improvements or alterations which may bo carried out in foreign armies. Taking, for example, the thirteenth and fourteenth volumes issued during the two half-years of 1878, we find the following countries drawn upon:Afghanistan, Alsace-Lorraine, England, Anstria, Hungary, Bulgaria, Denmark, Germany, Spain, Greece, Holland, Italy, Japan, Roumania, Russia, Servia, Nozway and Sweden, Switzerland, Turkey.

The subjects treated comprise-Administration, Small Arms, SmallArm Practice, Mlilitary Art, Tactics, Artillery, Military Budgets, Camps of Assembly and of Exercise, Cavally, Remounts, Railways, Staff, Study of Theatres of War, Fortification, Engineering, Military History, Infantry, Mrilitary Education, Maritime Affairs (to a sliglit extent), Medical Department, Mobilization, Organization, Recruiting, Statistics, Mrilitary T'elegraphy, and Signalling:

In the articles whicin form the main portion of each number, criticism occupies a secondary position altogether. The chief object of the publication, namely, the dissemination of information, is steadily kept in 
view. Sometimes, as in the case of tacties at, the present time, when a controversy is being carricd on, and discussions are taking place among Continental soldiers, the Revue performs the part of judge, so far as laying before its readers the most important arguments on either side of the dispute. As an instance of this, may be quoted the series of articles commenced in 1877, and not yet conclnded, entitled "Les "Procélés Tactiques de la Guerre d'Orient." As a corollary to the original subject, the views held on the Continent with regard to the tactics of the future, and the bearing on them of intrenchments and long-range infantry fre, are now being placed before military men. In another branch of military science, viz., the training of the reserve forces, valuable information is afforded in connection with the German Landwehr. Another noticeable feature of the Revue are the "Nou"velles Militaires," sloort paragraphs, frequently giving most valuable items of intelligence.

The Revue in some respects resembles the Journal, which, in our days, Albert Smith used to designate as the "Amiable Pirate," inasmuch as there is not a periodical of ans value in Europe which, through translations or otherwise, is not drawn on for information.

It seems extraordinars that a work of such value shonld have in our Army so limited a circulation; because to us, left behind as we have been during the last half-century in much that appertains to army organization and field work, it is a matter of the greatest importance to learn exactly what is being done in other armies, and to have before us the standard of improvement which the most advanced have reached, and to which our own Army can easily attain if only the nation give tlio word.

Napoleon, in his description of the qualifications of a General, included a knowledge of foreign military matters. The same knowledge would appear to be necessary also to the Staff who may have to assist the Generals in carrying on operations. But regimental Officers would equally profit by perusing the Revue. The caralry Officer, thirsting for information as to the higher leading of his arm, and finding English literature somewhat deficient in this branch of our profession, will in the pages of the Revue find acconnts of the methods recommended abroad, and moreover the sources whence he can obtain further particulars. Artillery, Engineers, and Infantry will, each and all, find articles treating of their branches of the Service.

It is not too much to say, that any one who steadily digests this weekly budget of foreign military information will be kept perfectly wu covrant to everything of importance which is taking place in the countries with which it deals. The subscription, post free, is only 16 francs. The Revue can bo obtained cither through any English bookseller, or direct from Paris. The name and address of the administrateur is A. de Forges, 152, Ruo Montmartre.

LoXsdale Hale. 